\title{
Tumor necrosis factor-alpha induces VCAM-1- mediated inflammation via c-Src-dependent transactivation of EGF receptors in human cardiac fibroblasts
}

\author{
Chih-Chung Lin ${ }^{1,2}$, Chih-Shuo Pan ${ }^{3,4}$, Chen-Yu Wang ${ }^{3,4}$, Shiau-Wen Liu ${ }^{1,2}$, Li-Der Hsiao ${ }^{1,2}$ and Chuen-Mao Yang ${ }^{3,4^{*}}$
}

\begin{abstract}
Background: Tumor necrosis factor-a (TNF-a) is a proinflammatory cytokine and elevated in the regions of tissue injury and inflammatory diseases. The deleterious effects of TNF-a on fibroblasts may aggravate heart inflammation mediated through the up-regulation of adhesion molecules such as vascular cell adhesion molecule-1 (VCAM-1). However, the mechanisms underlying TNF-a-induced VCAM-1 expression in cardiac fibroblasts remain unknown. This study aimed to investigate the roles of TNF-a in VCAM-1 expression and its effects on human cardiac fibroblasts (HCFs).
\end{abstract}

Results: The primary culture HCFs were used in this study. The results obtained with Western blotting, real time-quantitative PCR, and promoter activity analyses showed that TNF-a-induced VCAM-1 expression was mediated through TNF receptor (TNFR) 1-dependent gene up-regulation. Activation of TNFR1 by TNF-a transactivated c-Src-dependent EGF receptor (EGFR) linking to PI3K/Akt cascade, and then led to transcriptional activity of NF-KB. Moreover, the results of promoter reporter assay demonstrated that the phosphorylated p65 NF-KB turned on VCAM-1 gene expression. Subsequently, up-regulation of VCAM-1 promoted monocytes adhesion to HCFs challenged with TNF-a determined by cell adhesion assay.

Conclusions: Taken together, these results indicate that in HCFs, activation of NF-kB by c-Src-mediated transactivation of EGFR/PI3K/Akt cascade is required for TNF-a-induced VCAM-1 expression. Finally, increased VCAM-1 enhances monocytes adhering to HCFs challenged with TNF-a. Understanding the mechanisms of VCAM-1 up-regulated by TNF-a on HCFs may provide rationally therapeutic interventions for heart injury or inflammatory diseases.

Keywords: TNF-a, Cardiac fibroblasts, EGFR transactivation, VCAM-1, Monocytes adhesion

\section{Background}

Heart failure, the first cause of death in the world, is generally defined as the inability of heart supplying sufficient blood volume and is a progressive and complex pathological condition [1]. The most common initiation leading to heart failure is coronary artery disease with myocardial infarction and hypertension

\footnotetext{
* Correspondence: chuenmao@mail.cgu.edu.tw

${ }^{3}$ Department of Physiology, College of Medicine, Chang Gung University, Kwei-Shan, Tao-Yuan, Taiwan

${ }^{4}$ Department of Pharmacology and Health Aging Research Center, College of Medicine, Chang Gung University, 259 Wen-Hwa 1st Road, Kwei-Shan,

Tao-Yuan, Taiwan

Full list of author information is available at the end of the article
}

$[2,3]$. The previous study indicates that pathological fibrosis has emerged as a key target for pharmacological intervention in heart failure [4]. Several proinflammatory cytokines such as tumor necrosis factor- $\alpha$ $(\mathrm{TNF}-\alpha)$ are elevated in acute myocardial injury and infarction. Chronically elevated these cytokines also have been shown to cause phenotypic and functional changes in the constituent cell types of the heart [5-8], including cell proliferation, production of the collagen extracellular matrix $(\mathrm{ECM})$, generation of mediator substances by the cardiac fibroblast [9-11], and associate with heart failure [12].

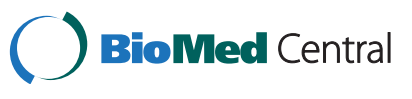

(C) 2015 Lin et al. This is an Open Access article distributed under the terms of the Creative Commons Attribution License (http://creativecommons.org/licenses/by/4.0), which permits unrestricted use, distribution, and reproduction in any medium, provided the original work is properly credited. The Creative Commons Public Domain Dedication waiver (http:// creativecommons.org/publicdomain/zero/1.0/) applies to the data made available in this article, unless otherwise stated. 
TNF- $\alpha$ is a major cytokine in the pathogenesis of cardiac injury, promoting inflammation, apoptosis, and production of ECM [13, 14] and exerts as a potent stimulus in inflammatory responses through upregulation of many genes, including cytokines, chemokines, proteases, cyclooxygenase, and adhesion molecules $[15,16]$. Furthermore, inhibition of TNF- $\alpha$-mediated pathways can reduce myocardial ischemia-reperfusion injury [13]. These results suggest that TNF- $\alpha$ may act as a key mediator to elicit various heart diseases. TNF- $\alpha-$ activated NF- $\mathrm{kB}$ is critical for the inflammatory processes $[17,18]$. In addition, TNF- $\alpha$ induces the expression of inflammatory genes by activation of TNF receptor (TNFR)-mediated diverse signaling molecules, including c-Src family $[19,20]$. As already shown in human cardiac fibroblasts MMP-9 expression is induced by TNF- $\alpha$ [16]. Furthermore, our previous data showed that TNF- $\alpha$ can induce MMP-9 expression through a c-Src/EFGR [6]. The c-Src family, a non-receptor tyrosine kinase, has been shown to exert as a target of $G$ protein-coupled receptors (GPCRs) in transactivation of growth factor receptors such as epidermal growth factor receptor (EGFR) [21] and also involves in cytokine-stimulated transactivation of growth factor receptors like EGFR in several cell types [22].

In the serum of patients with non-ischemic heart failure, the levels of intercellular adhesion molecule (ICAM)-1 and vascular cell adhesion molecule (VCAM)-1 are often elevated. And the cellular infiltration is due to upregulation of adhesion molecules including ICAM-1 and VCAM-1 to control cell adhesion and migration [23-26]. These raised levels of adhesion molecules correlate with inflammatory infiltrates in the myocardial tissue [27]. VCAM-1, which exhibits low to negligible expression in unstimulated endothelial cells, can be profoundly upregulated after cytokine challenge. The induction of cell adhesion molecules mediates the tight adhesiveness of polymorphonuclear cells (PMNs) and thus facilitates PMNs migration across the vascular endothelial barrier $[28,29]$. Up-regulation of VCAM-1 and TNF- $\alpha$ has been shown in the cardiac vascular endothelium from the patients with chronic heart failure [27, 30]. TNF- $\alpha$-activated $\mathrm{c}-\mathrm{Src}$ kinase and NF- $\mathrm{kB}$ can regulate VCAM-1 expression [31-33] and the soluble ICAM-1 release from osteoblastlike MC3T3-E1 cells [34]. VCAM-1 promoter also contains $\mathrm{NF}-\kappa \mathrm{B}$ binding sites which are regulated by TNF- $\alpha$ through c-Src-dependent pathways [19]. Therefore, cytokine-triggered VCAM-1 up-regulation in heart diseases may be the key response for the targeted leukocyte transmigration into extravascular space of inflammation [29, 35]. However, the mechanisms and effects of TNF- $\alpha$ on VCAM-1 expression via the activation of $\mathrm{c}-\mathrm{Src}$ and $\mathrm{NF}-\mathrm{kB}$ in primary human cardiac fibroblasts (HCFs) remain unclear.
In this study, we found that TNF- $\alpha$ induces c-Srcmediated signal activation in HCFs via TNFR1, in turn initiates the activation of EGFR, PI3K/Akt, and NF- $\mathrm{kB}$. Activated NF- $\mathrm{B}$ could accelerate VCAM-1 promoter activity to induce VCAM-1 expression in HCFs. Moreover, up-regulation of VCAM-1 promoted adhesion of monocytes to HCFs challenged with TNF- $\alpha$. These results provide new insights into the TNF- $\alpha$ action, to up-regulate the VCAM-1 expression and then amplify the inflammatory responses in HCFs.

\section{Methods \\ Materials}

DMEM/F-12 medium, fetal bovine serum (FBS), TRIZOL, Lipofectamine-PLUS reagent and 2',7'-bis-(2-carboxyethyl)-5-(and-6)-carboxyfluorescein, acetoxymethyl ester (BCECF/AM, B-1170) were from Invitrogen (Carlsbad, CA). The siRNAs for TNFR1 (NM_001065, SASI_Hs01_ 00033456), c-Src (NM_005417, SASI_Hs01_00097530), EGFR (NM_005228, SASI_Hs01_00215449), p110 (NM_ 006218, SASI_Hs01_00219339), Akt (NM_001014431, SASI_Hs01_00105954), and p65 (a subunit of NF-кB, NM_021975, SASI_Hs01_001220265) were from Sigma (St. Louis, MO). Hybond C membrane, enhanced chemiluminescence (ECL) and Western blotting detection system were from GE Healthcare Biosciences (Buckinghamshire, UK). PhosphoPlus EGFR (Thr ${ }^{1068}$ ) (\#2236), Akt (Ser $\left.{ }^{473}\right)$ (\#9271), and p65 NF-kB (Ser $\left.{ }^{536}\right)$ (\#3031) antibody kits were from Cell Signaling (Danvers, MA). Human polyclonal antibody VCAM-1 (sc-8304), TNFR1 (sc-52739), phospho-c-Src $\left(\mathrm{Tyr}^{139}\right.$ ) (sc-12928-R), c-Src (sc-18), p110 (PI3K subunit) (sc-7189), Akt (sc8312), and p65 (sc-7151) antibodies were from Santa Cruz (Santa Cruz, CA). Vimentin (MS-129-P) was from Thermo Fisher Scientific (Fremont, CA). GAPDH was from Biogenesis (Bournemouth, UK). Peroxidase AffiniPure goat anti-rabbit IgG (111-035-003) and anti-mouse IgG (115-035-003) were from Jackson ImmunoResearch (West Grove, PA). PP1, AG1478, LY294002, SH-5, and Bay11-7082 were from Biomol (Plymouth Meeting, PA). TNF- $\alpha$ was from R\&D Systems (Minneapolis, MN). Bicinchoninic acid (BCA) protein assay kit was from Pierce (Rockford, IL). Actinomycin D (Act. D), cycloheximide (CHI), enzymes, and other chemicals were from Sigma (St. Louis, MO).

\section{Human cardiac fibroblasts (HCFs) culture and treatment} Human cardiac fibroblasts (HCFs) were isolated from human heart obtained from ScienCell Research Lab (San Diego, CA, Cat. No. 6300) and then characterized by immunofluorescent staining with an antibody specific to fibronectin [36]. These cells were grown in DMEM/F-12 containing $10 \%$ FBS, $2 \mathrm{mM}$ glutamine and antibiotics 
(100 U/ml penicillin $\mathrm{G}, 100 \mu \mathrm{g} / \mathrm{ml}$ streptomycin, and $250 \mathrm{ng} / \mathrm{ml}$ fungizone) at $37{ }^{\circ} \mathrm{C}$ in a humidified $5 \% \mathrm{CO}_{2}$ atmosphere. When the cultures reached confluence, cells were treated with $0.05 \%$ trypsin/0.53 mM EDTA for $1 \mathrm{~min}$ at $37{ }^{\circ} \mathrm{C}$. The cell suspension was diluted with DMEM/F-12 containing $10 \%$ FBS and $2 \mathrm{mM}$ glutamine to a concentration of $2 \times 10^{5}$ cells $/ \mathrm{ml}$. The cells were plated onto 12-well culture plates and made quiescent at confluence by incubation in serum-free DMEM/F-12 for $24 \mathrm{~h}$, for growth arrest as previously described $[9,37]$, and then incubated with TNF- $\alpha(0.15,1.5,15$, or $30 \mathrm{ng} /$ $\mathrm{ml})$ at $37{ }^{\circ} \mathrm{C}$ for the indicated time intervals. The XTT \{sodium 3'-[1-(phenylamino-carbonyl)-3,4-tetrazolium]bis(4-methoxy-6-nitro) benzene sulphonic acid hydrate assay was performed to analyze the cell viability as previously described [38]. When the inhibitors were used, cells were pretreated with the inhibitor for $1 \mathrm{~h}$ before exposure to TNF- $\alpha$. Treatment of HCFs with pharmacological inhibitors or TNF- $\alpha$ alone had no significant effect on cell viability determined by XTT assay (data not shown). Experiments were performed using cells from passages 3 to 8 .

\section{Preparation of cell extracts and Western blot analysis} Growth-arrested HCFs (incubation in serum-free DMEM/ F-12 for $24 \mathrm{~h}$ ) were incubated with TNF- $\alpha$ at $37^{\circ} \mathrm{C}$ for the indicated time intervals. The cells were washed with icecold PBS, scraped, and collected by centrifugation at $45,000 \times \mathrm{g}$ for $1 \mathrm{~h}$ at $4{ }^{\circ} \mathrm{C}$ to yield the whole cell extract, as previously described [33]. Samples were denatured, subjected to SDS-PAGE using a $10 \%(\mathrm{w} / \mathrm{v})$ running gel, and transferred to nitrocellulose membrane. Membranes were incubated overnight using a phospho-c-Src, phosphoEGFR, phospho-Akt, phospho-p65, TNFR1, EGFR, p110, Akt, p65, or GAPDH antibody. Membranes were washed with TTBS four times for $5 \mathrm{~min}$ each, incubated with a 1:2000 dilution of anti-rabbit horseradish peroxidase antibody for $1 \mathrm{~h}$. The immunoreactive bands were detected by ECL reagents and captured by a UVP BioSpectrum 500 Imaging System (Upland, CA). The image densitometry analysis was quantified by UN-SCAN-IT gel software (Orem, UT).

\section{Total RNA extraction and real time-quantitative PCR (RT-qPCR) analysis}

Total RNA was isolated from HCFs treated with TNF- $\alpha$ for the indicated time in 10-cm culture dishes with Trizol according to the protocol of the manufacturer. The cDNA obtained from total RNA previously described [33]. RT (reverse transcription) of the first-strand cDNA synthesis was performed with $2 \mu \mathrm{g}$ of total RNA using oligo-dT as primers in a final volume of $20 \mu \mathrm{l}(2 \mathrm{U} / \mu \mathrm{l}$ RNaseOUT, Cat. 10777-019, and $10 \mathrm{U} / \mu \mathrm{l}$ Moloney murine leukemia virus reverse transcriptase (Cat. 28025-013) from Invitrogen (Carlsbad, CA). The reaction was carried out at $37^{\circ} \mathrm{C}$ for $60 \mathrm{~min}$.

Real-time PCR using KAPA PROBE FAST ABI Prism qPCR kit (KK4705, Kapa Biosystems, Wilmington, MA) was performed with the 7500 Real-Time PCR System (Applied Biosystems, Foster City, CA) using primers and probe mixes for VCAM-1 (Forward: WSO_645213_001; Reverse: WSO_645213_002; Probe: WSO_645213_003; Invitrogen) and endogenous GAPDH (Forward: WSO_ 724786_001; Reverse: WSO_724786_002; Probe: WSO_ 724786_003) served as an internal control gene (Invitrogen, Carlsbad, CA). Relative gene expression was determined by the $\Delta \Delta \mathrm{Ct}$ method, where Ct meant threshold cycle [39]. All experiments were performed in triplicate.

\section{Plasmid construction, transfection, and luciferase reporter gene assays}

For construction of the VCAM-1-Luc plasmid, human VCAM-1 promoter, a region spanning -1716 to $-119 \mathrm{bp}$ (kindly provided by Dr. W.C. Aird, Department of Molecular Medicine, Beth Israel Deaconess Medical Center, Boston, MA, USA) was inserted between MluI and XhoI sites of pGL3-basic vector (Promega, Madison, WI). All plasmids were prepared by using QIAGEN plasmid DNA preparation kit. Plasmid (or siRNA) transient transfection of HCFs was performed according to the protocol of Lipofectamine and PLUS reagent (Invitrogen, Carlsbad, CA) with minor modifications. Briefly, HCFs were plated at $3 \times 10^{5}$ cells $/ \mathrm{ml}(1 \mathrm{ml}$ per well) in 12-well culture plates for $24 \mathrm{~h}$, reaching about $80 \sim 90 \%$ confluence. Cells were washed once with PBS and $0.4 \mathrm{ml}$ of serum-free DMEM/F-12 medium was added to each well. The $0.8 \mu \mathrm{g}$ plasmid DNA (or 20 pmol siRNA) and $1 \mu \mathrm{l}$ PLUS reagent complex were prepared with serumand antibiotics-free DMEM/F-12 for $15 \mathrm{~min}$ at room temperature. Two $\mu \mathrm{l}$ Lipofectamine ${ }^{\text {tm }}$ was mixed gently with serum- and antibiotics-free DMEM/F-12. The mixtures were incubated for $30 \mathrm{~min}$ at room temperature. The mixtures $(100 \mu \mathrm{l})$ were added into the wells. After transfection for $5 \mathrm{~h}$, the cells were washed once with PBS and $0.5 \mathrm{ml}$ of containing $10 \%$ FBS was added and incubated for an additional $19 \mathrm{~h}$. VCAM-1-Luc and $\mathrm{kB}$ Luc (Clontech, Palo Alto, CA) activities in HCFs were determined as previously described [33] using a luciferase assay system (Promega, Madison, WI) according to the manufacturer's instructions. Firefly luciferase activities were standardized for $\beta$-galactosidase activity.

\section{Cell adhesion assay}

HCFs were placed on 6-well culture plates with cover slips and pretreated with the pharmacological inhibitors for $1 \mathrm{~h}$ before treatment with TNF- $\alpha$ for $16 \mathrm{~h}$ at $37^{\circ} \mathrm{C}$ in a humidified $5 \% \mathrm{CO}_{2}$ atmosphere. Before the adhesion 
assay, the HCFs were washed with PBS and then incubated in serum-free DMEM/F-12. THP-1 cells (human acute monocytic leukemia cell line, obtained from ATCC) were maintained in suspension in RPMI-1640 medium supplemented with $10 \%$ FBS, $100 \mathrm{U}$ penicillin, and $100 \mathrm{U}$ streptomycin. Before labeling, THP-1 cells were washed and resuspended in serum-free medium. BCECF/AM $(10 \mu \mathrm{M})$, a membrane-permeable fluorescent indicator with an $\mathrm{Ex} / \mathrm{Em}=503 / 520 \mathrm{~nm}$, was used to label the THP-1 cells in serum free medium for $1 \mathrm{~h}$ at $37{ }^{\circ} \mathrm{C}$. After labeling, cells were washed and resuspended in serum free medium at least three times and kept in the dark at room temperature and then the labeled THP- 1 cell $\left(2 \times 10^{6}\right.$ cells $\left./ \mathrm{ml}\right)$ were added to HCFs challenged with TNF- $\alpha$, and cultures were incubated in a $\mathrm{CO}_{2}$ incubator for $1 \mathrm{~h}$. Non-adherent THP-1 cells were removed and plates were gently washed twice with PBS. The numbers of fluorescently labeled adherent THP-1 cells were determined by counting four fields per $200 x$ high-power field well using a fluorescence microscope (Zeiss, Axiovert $200 \mathrm{M}$ ).

\section{Statistical analysis}

All data were estimated using GraphPad Prism Program (GraphPad, San Diego, CA). Data were expressed as the mean \pm SEM and analyzed with a one-way ANOVA followed with Wilcoxon/Kruskal-Wallis test at $p<0.05$ level of significance.

\section{Results}

TNF- $a$ induces VCAM-1 expression and monocyte adhesion

To evaluate the effect of TNF- $\alpha$ on VCAM-1 protein and mRNA expression, HCFs were incubated with various concentrations of TNF- $\alpha$ for the indicated time intervals. As shown in Fig. 1a, TNF- $\alpha$ induced VCAM-1 protein expression in a time- and concentration-dependent manner, with a significant increase within $4 \mathrm{~h}$, a maximal response within $16 \mathrm{~h}$, and sustained over $24 \mathrm{~h}$. There was no change in the levels of house-keeping protein GAPDH served as an internal control. We also found that $30 \mathrm{ng} / \mathrm{ml}$ TNF- $\alpha$ induced a maximal VCAM-1 induction within 16-24 $\mathrm{h}$. The concentration of TNF- $\alpha$ $(15 \mathrm{ng} / \mathrm{ml})$ was used to induce sub-maximal VCAM-1 expression for the following experiments. To further examine the effect of TNF- $\alpha$ on VCAM-1 mRNA expression, the levels of VCAM-1 mRNA were determined by real time-qPCR. As shown in Fig. 1b, TNF- $\alpha$ (15 ng/ml) time-dependently induced VCAM-1 mRNA accumulation in HCFs. A maximal response was obtained within $4 \mathrm{~h}$ and sustained over $6 \mathrm{~h}$ during the period of observation. Moreover, TNF- $\alpha$ (15 ng/ml) also stimulated a significant increase in VCAM-1promoter activity within $2 \mathrm{~h}$ and reached a maximum within $4 \mathrm{~h}$ (Fig. 1c), suggesting that TNF- $\alpha$ upregulated VCAM-1 gene expression in HCFs. We further tested the functional activity of expressed VCAM- 1 by TNF- $\alpha$ in HCFs, a THP-1 monocyte adhesion assay was performed. As shown in Fig. 1d, TNF- $\alpha$ induced a significant increase of THP-1 monocyte adhesion to TNF- $\alpha$-challenged HCFs (approximate 4 folds) which was attenuated by pretreatment with VCAM-1 neutralizing antibody (VCAM-1 nAb, $2 \mu \mathrm{g} / \mathrm{ml}$ ). These results suggested that induction of VCAM-1 enhances THP-1 monocyte adhesion to the TNF- $\alpha$-challenged HCFs.

\section{TNF- $a$ induces de novo VCAM-1 protein synthesis via TNF receptor-mediated manner}

To determine whether the effect of TNF- $\alpha$ on VCAM-1 expression is dependent on de novo protein synthesis, a transcription inhibitor Act. D and a translation inhibitor $\mathrm{CHI}$ were used. As shown in Figs. 2a and b, pretreatment with either Act. D or $\mathrm{CHI}$ concentration-dependently attenuated TNF- $\alpha$-induced VCAM-1 expression in HCFs, suggesting that VCAM-1 expression induced by TNF- $\alpha$ is mediated through the transcription and translation. To determine whether TNF- $\alpha$-induced VCAM-1 expression is mediated through TNF receptor (TNFR), as shown in Fig. 2c, pretreatment with TNFR neutralizing antibody (TNFR $n A b$ ) attenuated TNF- $\alpha$-induced VCAM- 1 expression. Moreover, as shown in Fig. 2d, pretreatment with Act. D $(10 \mu \mathrm{M})$ or TNFR nAb $(3 \mu \mathrm{g} / \mathrm{ml})$ significantly attenuated TNF- $\alpha$-induced VCAM- 1 mRNA expression (open bar) and VCAM-1 promoter activity (gray bar). To confirm the role of TNFR1 in TNF- $\alpha$-induced VCAM-1 expression, the data showed that transfection with TNFR1 siRNA knocked down TNFR1 protein and attenuated the TNF- $\alpha$-induced VCAM- 1 expression (Fig. 2e), suggesting that TNF- $\alpha$-induced VCAM-1 expression is mediated through TNFR1-dependent manner in HCFs.

\section{Involvement of c-Src in TNF-a-induced VCAM-1 expression}

TNF- $\alpha$ has been shown to induce expression of adhesion molecules such as VCAM-1 in various cell types [33]. In addition, c-Src is a critical tyrosine kinase to regulate VCAM-1 expression in myoglobin-induced tubular injury [31]. Thus, we investigated whether c-Src involved in TNF- $\alpha$-induced VCAM-1 expression in HCFs. As shown in Figs. 3a and b, pretreatment with the inhibitor of c-Src (PP1) attenuated TNF- $\alpha$-induced VCAM-1 protein, mRNA, and promoter activity. To further observe whether TNF- $\alpha$ could stimulate $c$-Src activation linked to VCAM-1 expression, as shown in Fig. 3c, TNF- $\alpha$ stimulated c-Src phosphorylation in a time-dependent manner in these cells. We further confirmed the effect of c-Src on TNF- $\alpha$-induced responses, a c-Src siRNA 


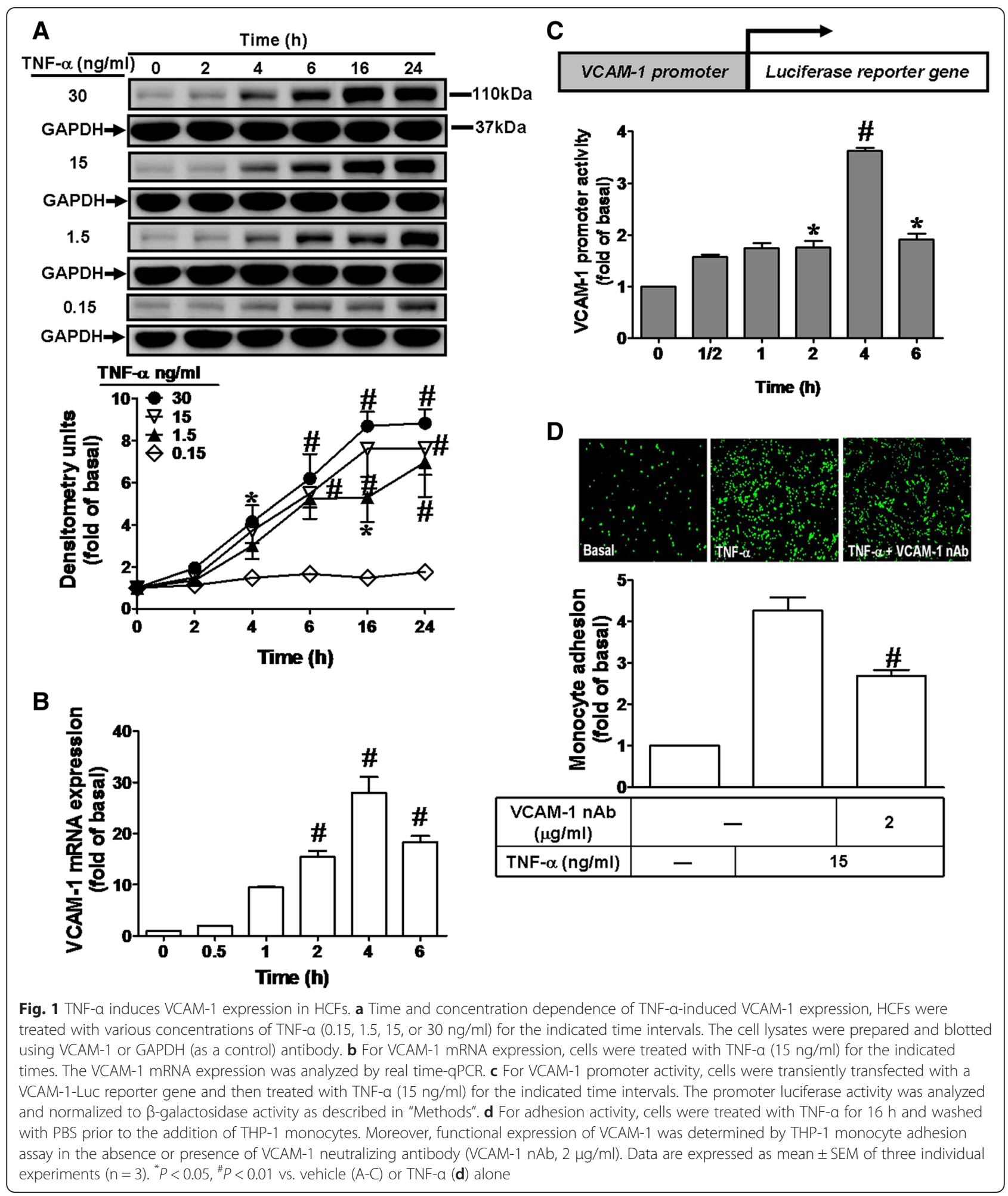

was used. The data showed that transfection with c-Src siRNA markedly knocked down c-Src protein level and attenuated TNF- $\alpha$-induced $\mathrm{c}$-Src phosphorylation (Fig. 3c) and VCAM-1 expression (Fig. 3d). Moreover, we determined the role of TNFR in these responses, as shown in Fig. 3e, pretreatment with TNFR nAb attenuated TNF- $\alpha$-stimulated $\mathrm{c}$-Src phosphorylation during the period of observation, suggesting that TNF- $\alpha$ stimulated c-Src phosphorylation via a TNFR-dependent manner. These results suggested that TNF- $\alpha$-induced 
A
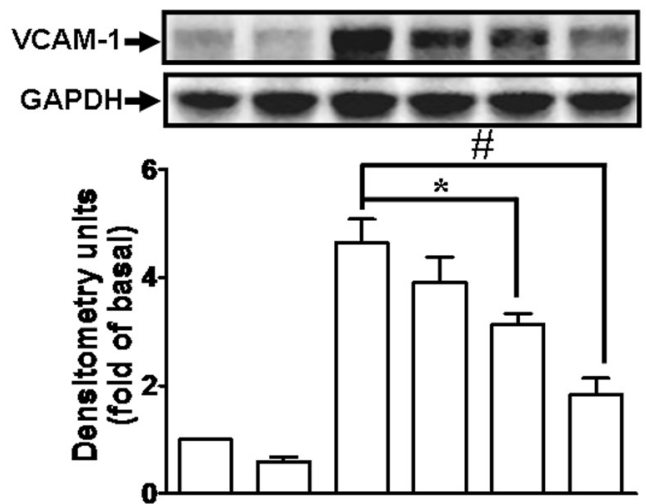

\begin{tabular}{|c|c|c|c|c|c|c|}
\hline Act. D $(\mu \mathrm{M})$ & - & 10 & - & 0.1 & 1 & 10 \\
\hline TNF- $\alpha(\mathrm{ng} / \mathrm{ml})$ & \multicolumn{2}{|c|}{-} & \multicolumn{5}{|c|}{15} \\
\hline
\end{tabular}

C
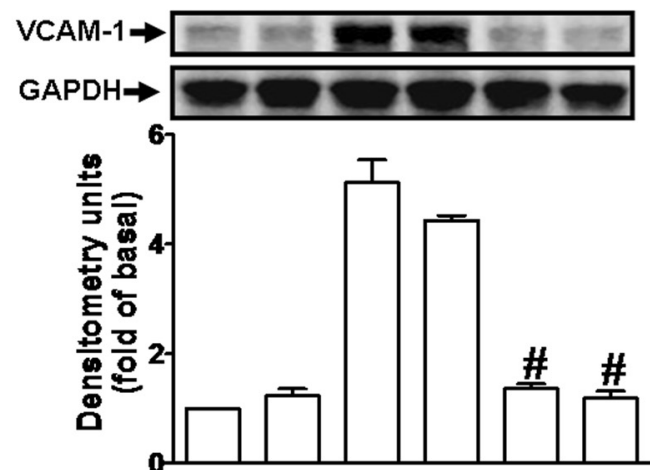
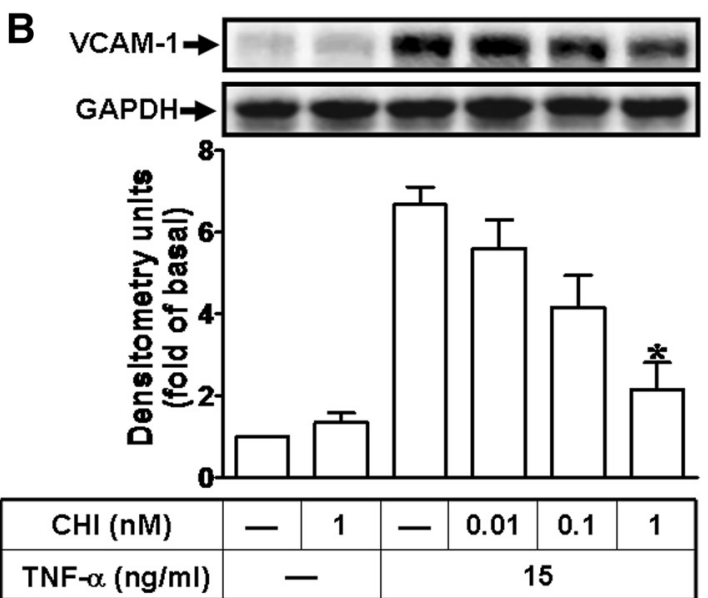

D

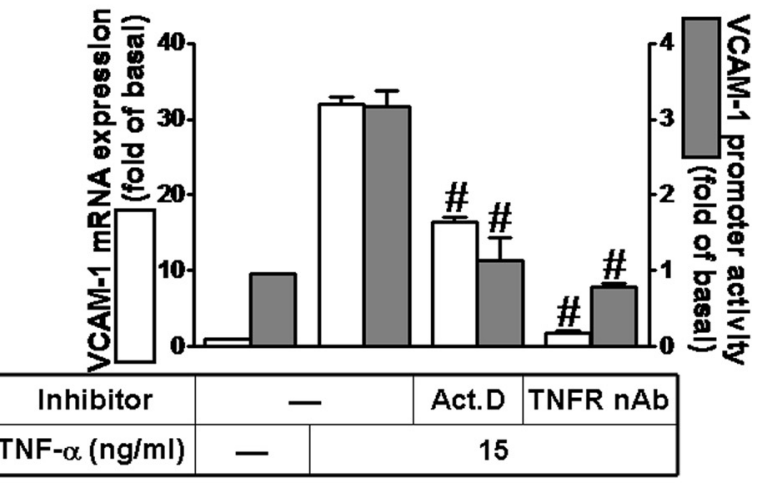

\begin{tabular}{|c|c|c|}
\hline Inhibitor & - & \begin{tabular}{|l|l} 
Act.D & TNFR $n A b$
\end{tabular} \\
\hline TNF- $\alpha(\mathrm{ng} / \mathrm{ml})$ & - & 15 \\
\hline
\end{tabular}

\begin{tabular}{|c|c|c|c|c|c|c|}
\hline CHI (nM) & - & 1 & - & 0.01 & 0.1 & 1 \\
\hline TNF- $\alpha(\mathrm{ng} / \mathrm{ml})$ & - & \multicolumn{4}{|c|}{15} \\
\hline
\end{tabular}

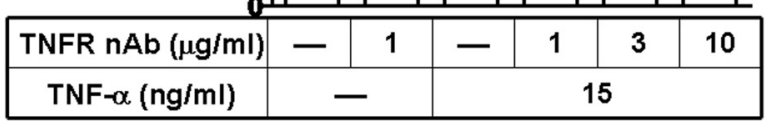

$\mathbf{E}$
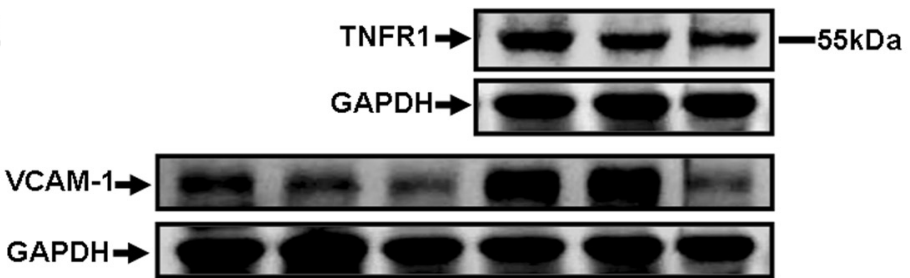

\begin{tabular}{|c|c|c|c|c|c|c|}
\hline siRNA & - & Scrb & TNFR1 & - & Scrb & TNFR1 \\
\hline TNF- $\alpha$ (ng/ml) & \multicolumn{3}{|c|}{-} & & \multicolumn{3}{c|}{15} \\
\hline
\end{tabular}

Fig. 2 TNF-a induces de novo VCAM-1 protein synthesis via TNFR1-mediated manner. a, b Cells were pretreated with various concentrations of actinomycin D (Act. D, transcription inhibitor) or cycloheximide ( $\mathrm{CHl}$, translation inhibitor) and then incubated with $15 \mathrm{ng} / \mathrm{ml}$ TNF-a for $16 \mathrm{~h}$. The cell lysates were analyzed by Western blot using a VCAM-1 or GAPDH (as a control) antibody. c Involvement of TNFR in TNF-a-induced VCAM-1 expression, cells were pretreated with various concentrations of TNFR neutralizing antibody (TNFR nAb; 1,3 , or $10 \mu \mathrm{g} / \mathrm{ml}$ ) for $1 \mathrm{~h}$ and then incubated with TNF-a for $16 \mathrm{~h}$. d Cells were pretreated with Act. D $(10 \mu \mathrm{M})$ or TNFR nAb $(3 \mu \mathrm{g} / \mathrm{ml})$ for $1 \mathrm{~h}$ and then incubated with TNF-a for $4 \mathrm{~h}$. The VCAM-1 mRNA (open bar) and promoter activity (gray bar) were analyzed by real time-qPCR and promoter assay, respectively. e Cells were transfected with siRNA of TNFR1 or scramble (scrb, as a control) for $24 \mathrm{~h}$ and then incubated with TNF-a for $16 \mathrm{~h}$. The VCAM-1 protein $(\mathbf{a}, \mathbf{b}, \mathbf{c}, \mathbf{e})$ was analyzed by Western blot using respective antibodies. Data are expressed as mean \pm SEM of three individual experiments $(n=3)$. ${ }^{*} P<0.05,{ }^{\#} P<0.01$ vs. TNF-a alone 


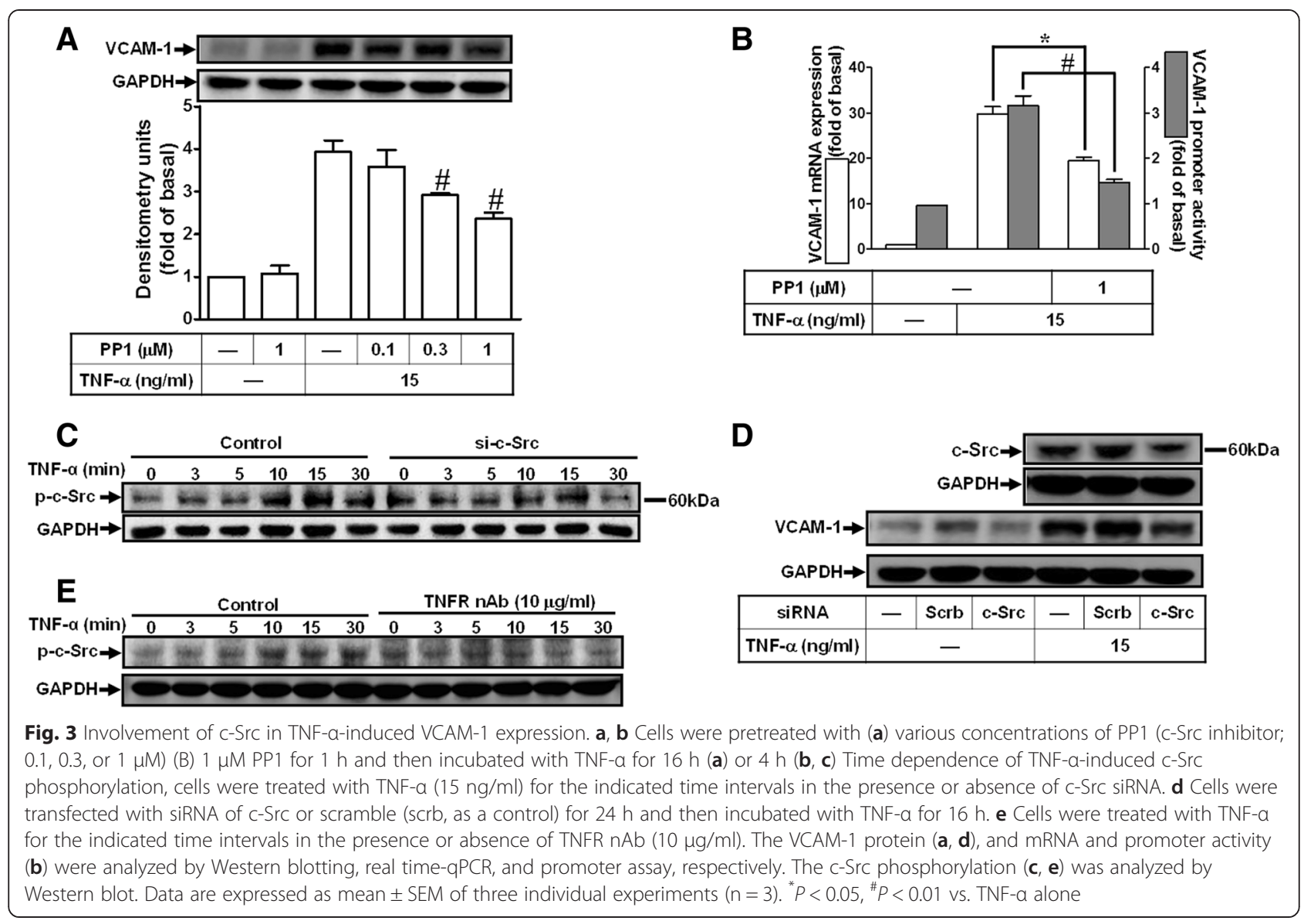

VCAM-1 expression is mediated through a c-Src-mediated pathway in HCFs.

\section{c-Src-dependent transactivation of EGFR is involved in TNF-a-induced VCAM-1 expression}

Several growth factor receptors such as EGFR activation have been shown to be regulated by c-Src leading to induction of various genes [40]. Thus, we investigated the role of EGFR in TNF- $\alpha$-induced VCAM-1 expression in HCFs. As shown in Figs. 4a and b, pretreatment with an EGFR inhibitor AG1478 concentration-dependently inhibited TNF- $\alpha$ induced VCAM-1 protein, mRNA, and promoter activity. To determine whether TNF- $\alpha$ could stimulate phosphorylation of EGFR linked to VCAM-1 expression, as shown in Fig. 4c, TNF- $\alpha$ time-dependently stimulated EGFR phosphorylation which was attenuated by pretreatment with AG1478 $(10 \mu \mathrm{M})$ during the period of observation. We further confirmed the role of EGFR in TNF- $\alpha$-induced VCAM-1 expression, the results showed that transfection with EGFR siRNA knocked down EGFR protein level and attenuated TNF- $\alpha$-induced VCAM-1 expression (Fig. 4d). We also investigated the role of TNFR-mediated c-Src cascade in TNF- $\alpha$-stimulated EGFR phosphorylation. As shown in Fig. 4e, pretreatment with TNFR nAb or PP1 attenuated TNF- $\alpha$-stimulated EGFR phosphorylation during the period of observation. These results suggested that c-Src-dependent EGFR transactivation contributes to TNF$\alpha$-induced VCAM-1 expression in HCFs.

\section{TNF- $\alpha$ induces VCAM-1 expression via PI3K/Akt cascade}

The PI3K/Akt signaling cascade, the direct downstream molecules of EGFR, plays a key role in various physiological and pathological processes. Previous studies have indicated that PI3K/Akt pathway is involved in VCAM-1 induction by TNF- $\alpha$ in various cell types $[40,41]$. In this study, we investigated the effects of PI3K (LY294002) and Akt (SH-5) inhibitors on TNF- $\alpha$-induced VCAM-1 expression. As shown in Figs. 5a and b, pretreatment with LY294002 or SH-5 markedly attenuated TNF- $\alpha$-induced VCAM-1 protein, mRNA, and promoter activity. To determine whether TNF- $\alpha$ stimulates activation of Akt, the data showed that TNF- $\alpha$ time-dependently stimulated Akt phosphorylation which was inhibited by pretreatment with LY294002 $(10 \mu \mathrm{M})$ during the period of observation (Fig. 5c). To confirm the roles of PI3K/Akt in TNF- $\alpha-$ induced VCAM-1 expression in HCFs, as shown in Fig. 5d, transfection with siRNA for p110 (a PI3K subunit) or Akt knocked down p110 or Akt protein, respectively, and 


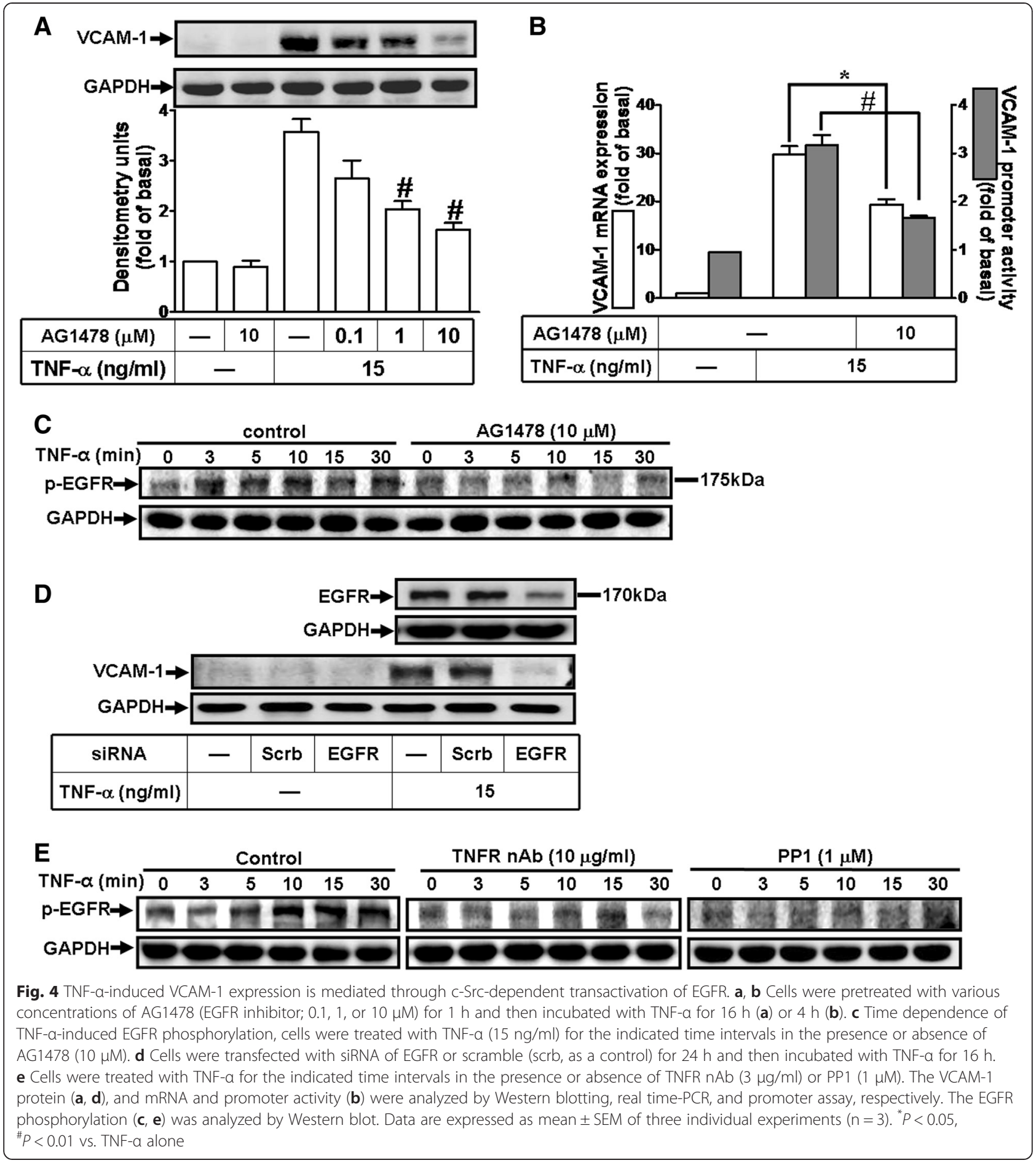

significantly attenuated TNF- $\alpha$-induced VCAM-1 expression. We further determined the role of c-Src-dependent EGFR signaling pathway in TNF- $\alpha$-stimulated Akt phosphorylation. As shown in Fig. 5e, pretreatment with TNFR nAb, c-Src siRNA, or AG1478 markedly attenuated TNF$\alpha$-induced Akt phosphorylation in HCFs. These results indicated that TNF- $\alpha$-induced VCAM-1 expression is mediated through a c-Src-dependent transactivation of EGFR-PI3K/Akt-dependent signaling pathway in HCFs.

NF-KB is required for TNF- $a$-induced VCAM-1 expression Inflammatory responses following stimulation with cytokines such as TNF- $\alpha$ are highly dependent on activation of the transcription factor NF- $\mathrm{kB}$. Moreover, TNF- $\alpha$ has 

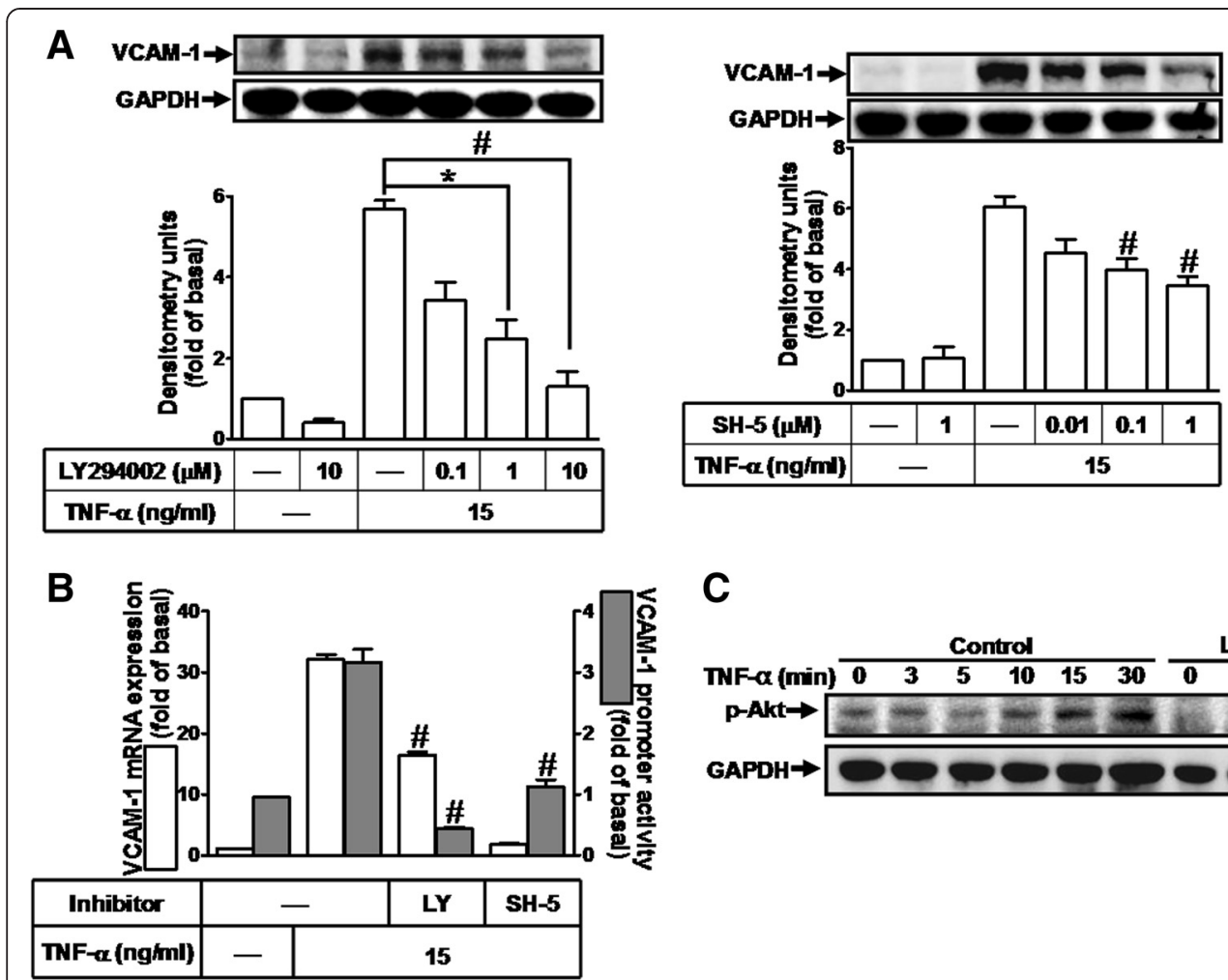

C
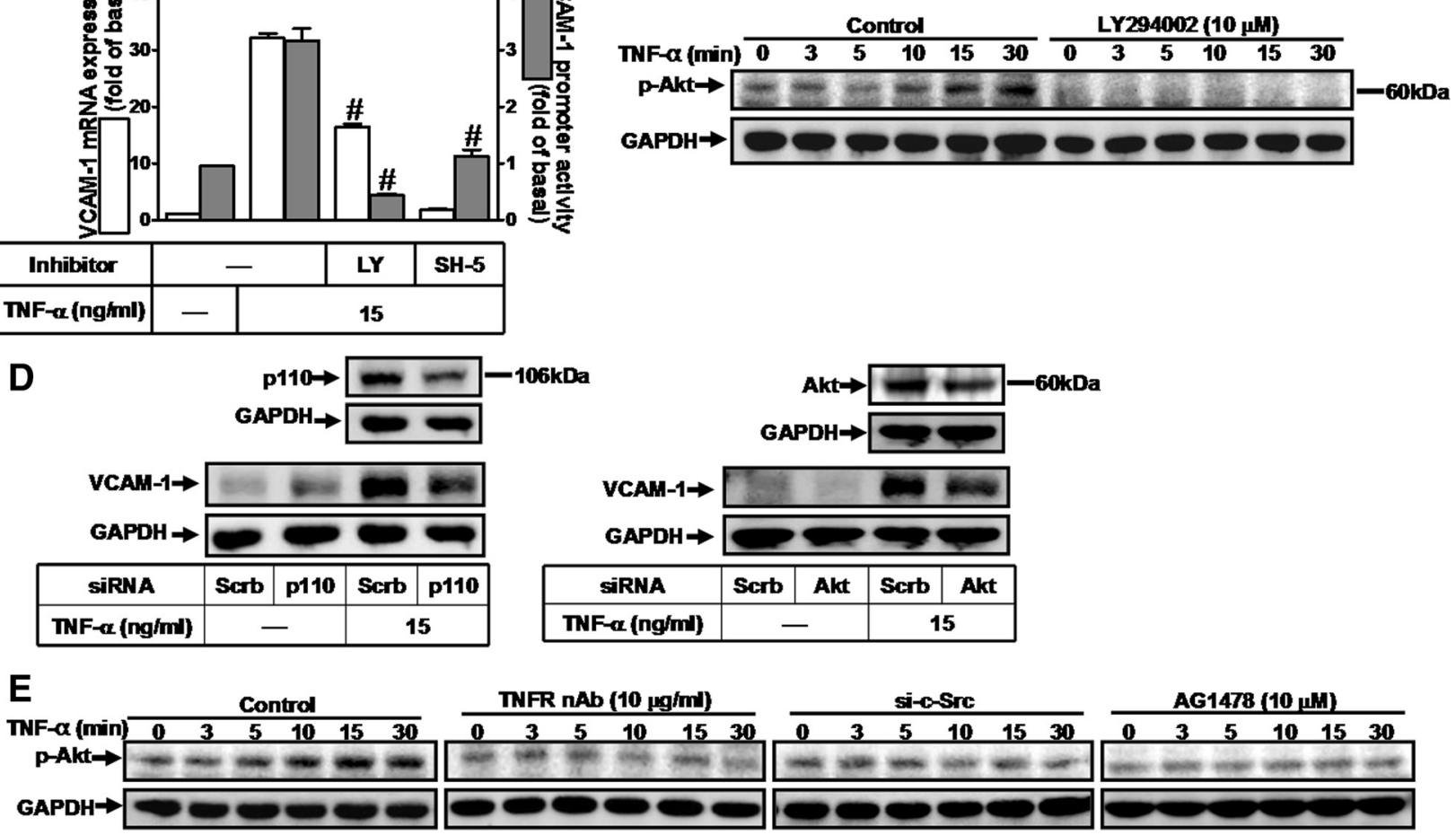

Fig. 5 TNF-a induces VCAM-1 expression via PI3K/Akt cascade. a, b Cells were pretreated with various concentrations of LY294002 (PI3K inhibitor; $0.1,1$, or $10 \mu \mathrm{M}$ ) or SH-5 (Akt inhibitor; 0.01, 0.1, or $1 \mu \mathrm{M}$ ) for $1 \mathrm{~h}$ and then incubated with TNF-a for $16 \mathrm{~h}(\mathbf{a})$ or $4 \mathrm{~h}$ (b). c Time dependence of TNF-a-induced Akt phosphorylation, cells were treated with TNF-a $(15 \mathrm{ng} / \mathrm{ml})$ for the indicated time intervals in the presence or absence of LY294002 (10 MM). d Cells were transfected with siRNA of p110 (a PI3K subunit), Akt, or scramble (scrb, as a control) for $24 \mathrm{~h}$ and then incubated with TNF-a for $16 \mathrm{~h}$. e Cells were treated with TNF-a for the indicated time intervals in the presence or absence of TNFR nAb (10 $\mu \mathrm{g} / \mathrm{ml})$, c-Src siRNA, or AG1478 $(10 \mu \mathrm{M})$. The VCAM-1 protein $(\mathbf{a}, \mathbf{d})$, and mRNA and promoter activity $(\mathbf{b})$ were analyzed by Western blotting, real time-PCR, and promoter assay, respectively. The Akt phosphorylation $(\mathbf{c}, \mathbf{e})$ was analyzed by Western blot. Data are expressed as mean \pm SEM of three individual experiments $(\mathrm{n}=3){ }^{*} P<0.05,{ }^{\#} P<0.01$ vs. TNF-a alone

been shown to induce expression of various genes such as VCAM-1 through NF-kB in several cell types [33]. Thus, the involvement of NF- $\kappa B$ in VCAM-1 induction by TNF$\alpha$ in HCFs was confirmed by using an NF- $\mathrm{kB}$ pharmacological inhibitor Bay11-7082. As shown in Fig. 6a, pretreatment with Bay11-7082 caused a concentrationdependent attenuation of VCAM-1 expression induced by TNF- $\alpha$ in HCFs. We further investigated the effects of
Bay11-7082 on TNF- $\alpha$-induced VCAM-1 mRNA and promoter activity. As shown in Fig. 6b, pretreatment with Bay11-7082 $(3 \mu \mathrm{M})$ attenuated TNF- $\alpha$-induced VCAM-1 mRNA and promoter activity. To determine whether TNF- $\alpha$ stimulates activation of NF- $\mathrm{kB}$, the data showed that TNF- $\alpha$ time-dependently stimulated p65 (a subunit of NF-kB) phosphorylation which was attenuated by pretreatment with Bay11-7082 during the period of 


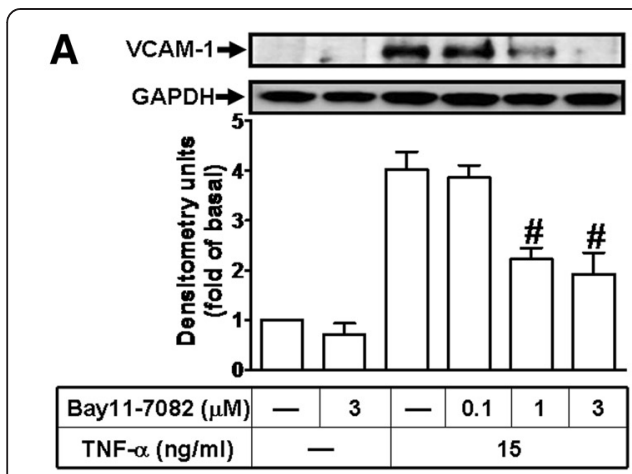

B

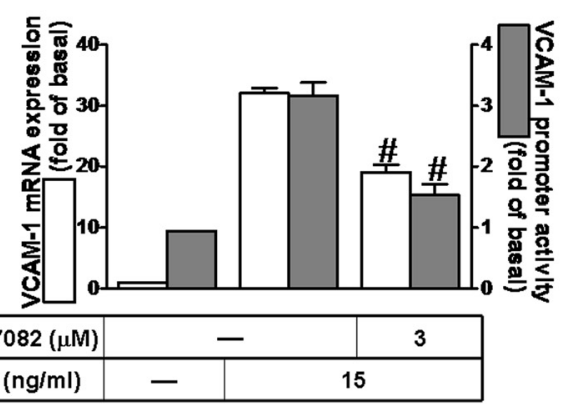

C

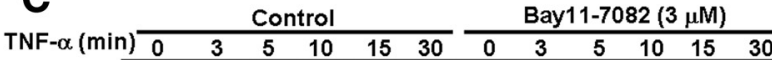
$\mathrm{p}-\mathrm{p} 65 \rightarrow-2-\ldots-\ldots-1-\ldots-1 \mathrm{kDa}$ $\mathrm{GAPDH} \rightarrow \longrightarrow$

D

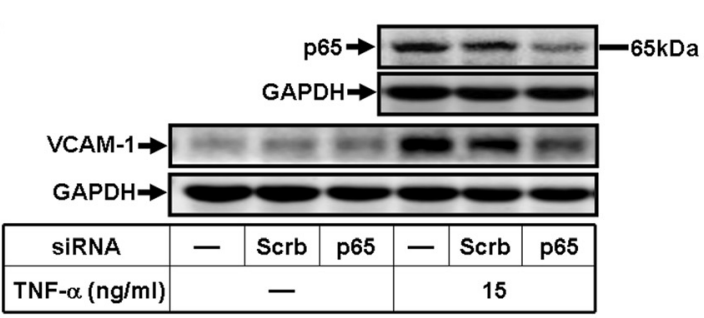

E

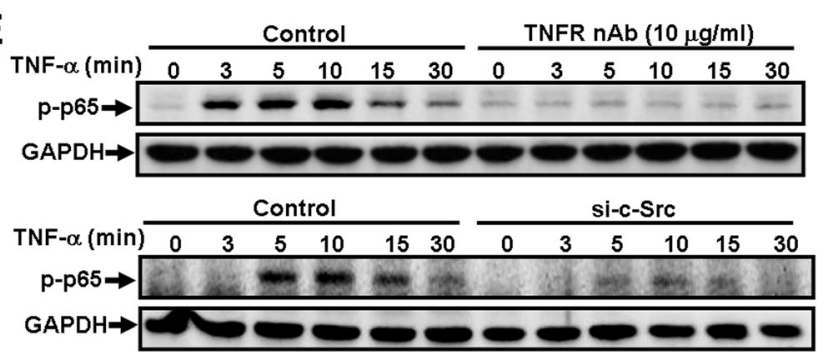

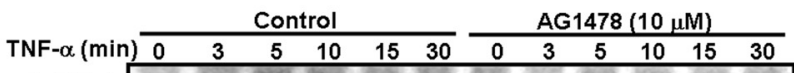

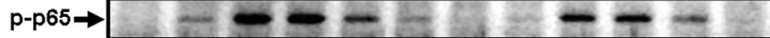
$\mathrm{GAPDH} \rightarrow \longrightarrow$

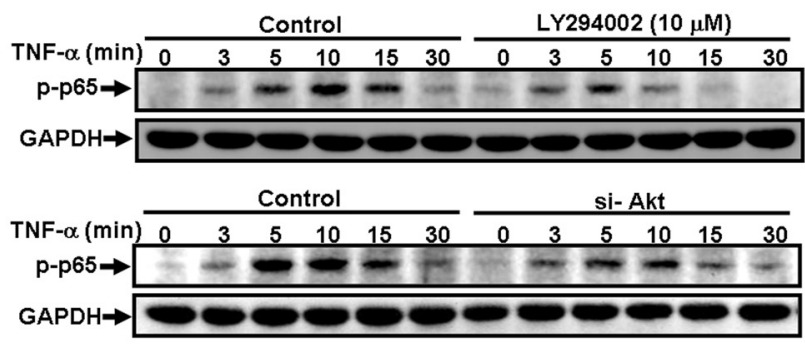

$\mathbf{F}$
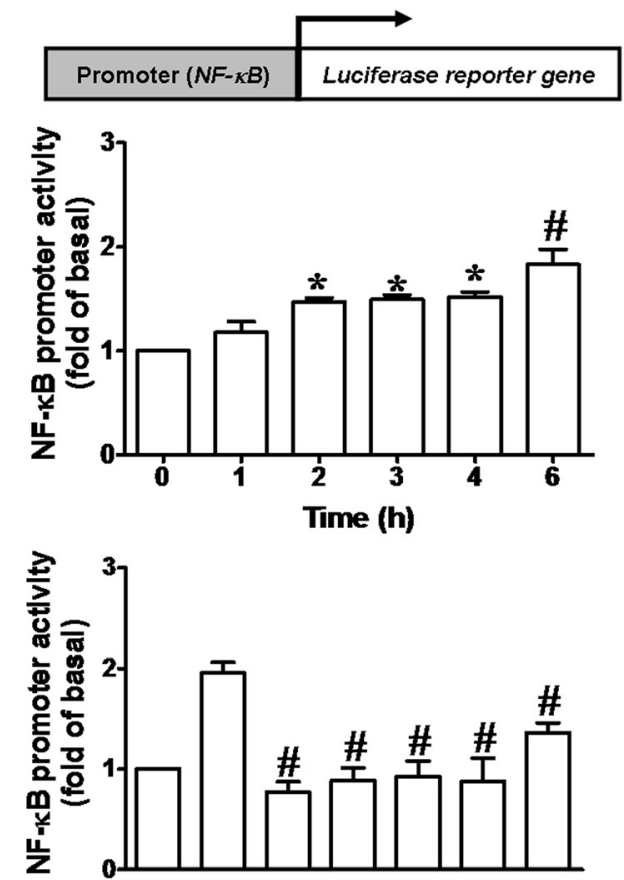

\begin{tabular}{|c|c|c|c|c|c|c|}
\hline Inhibitor & - & TNFR & PP1 & AG & LY & Bay \\
\hline TNF- $\alpha$ (h) & - & \multicolumn{5}{|c|}{6} \\
\hline
\end{tabular}

Fig. 6 (See legend on next page.) 
(See figure on previous page.)

Fig. 6 The NF-KB is required for TNF-a-induced VCAM-1 expression. a, b Cells were pretreated with various concentrations of Bay11-7082 (NF-KB inhibitor; 0.1, 1, or $3 \mu \mathrm{M}$ ) for $1 \mathrm{~h}$ and then incubated with TNF-a for $16 \mathrm{~h}$ (a) or $4 \mathrm{~h} \mathrm{(b).} \mathrm{c} \mathrm{Time} \mathrm{dependence} \mathrm{of} \mathrm{TNF-a-induced}$ p65 NF-KB phosphorylation, cells were treated with TNF-a $(15 \mathrm{ng} / \mathrm{ml})$ for the indicated time intervals in the presence or absence of Bay11-7082 (3 $\mu \mathrm{M})$. d Cells were transfected with siRNA of p65 or scramble (scrb, as a control) for $24 \mathrm{~h}$ and then incubated with TNF-a for $16 \mathrm{~h}$. e Cells were treated with TNF-a for the indicated time intervals in the presence or absence of TNFR nAb $(10 \mu \mathrm{g} / \mathrm{ml})$, c-Src siRNA, or AG1478 $(10 \mu \mathrm{M})$, LY294002 $(10 \mu \mathrm{M})$, or Akt siRNA. f Time dependence of TNF-a-stimulated NF-kB transcription activity, cells were transfected with a NFKB-luciferase reporter gene and then exposed to TNFa for the indicated time intervals (upper panel). Moreover, the transfected cells were pretreated with the inhibitor of NF-KB (Bay11-7082), TNFR nAb, c-Src (PP1), EGFR (AG1478), or PI3K (LY294002) for $1 \mathrm{~h}$ and then incubated with TNF-a for $6 \mathrm{~h}$ (lower panel). The VCAM-1 protein (a, d), mRNA (b), and promoter activity (b, $\mathbf{f})$ were analyzed by Western blotting, real time-qPCR, and promoter assay, respectively. The Akt phosphorylation $(\mathbf{c}, \mathbf{e})$ was analyzed by Western blot. Data are expressed as mean \pm SEM of three individual experiments $(n=3) .{ }^{*} P<0.05,{ }^{\#} P<0.01 \mathrm{vs}$. TNF- $a$ alone

observation (Fig. 6c). Furthermore, to confirm the role of NF- $\mathrm{kB}$ in TNF- $\alpha$-induced VCAM-1 expression, as shown in Fig. 6d, transfection with p65 siRNA knocked down p 65 protein level and attenuated TNF- $\alpha$-induced VCAM-1 expression, suggesting that NF- $\mathrm{kB}$ is essential for these responses. We further determined whether involvement of c-Src-dependent EGFR/PI3K/Akt signaling pathway in TNF- $\alpha$-stimulated p 65 phosphorylation in HCFs. As shown in Fig. 6e, pretreatment with TNFR nAb, c-Src siRNA, AG1478, LY294002, or Akt siRNA markedly attenuated TNF- $\alpha$-stimulated p65 phosphorylation, suggesting that TNFR/c-Src/EGFR/PI3K/Akt cascade is involved in TNF- $\alpha$-stimulated p65 phosphorylation in HCFs. Moreover, to determine whether TNF- $\alpha$ enhances the transcriptional activity of NF-kB, as shown in Fig. 6f, we observed that TNF- $\alpha$ enhanced NF-kB transcriptional activity in a time-dependent manner and a maximal response was achieved within $6 \mathrm{~h}$ (upper panel), which was markedly inhibited by pretreatment with TNFR nAb, PP1, AG1478, LY294002, or Bay11-7082 (lower panel). Taken together, these data demonstrated that TNF$\alpha$ induces NF-kB-dependent VCAM-1 expression via a TNFR/c-Src/EGFR/PI3K/Akt signaling pathway in HCFs.

\section{TNF-a promotes monocyte adhesion to HCFs through a c-Src-dependent EGFR/PI3K/Akt/NF-kB pathway}

Our previous data (Fig. 1d) have shown that TNF- $\alpha$ induces VCAM-1 expression and then enhancing monocyte adhesion to HCFs. Subsequently, we further investigated whether these signaling molecules investigated above are involved in enhancing monocyte adhesion to HCFs challenged with TNF- $\alpha$ and their respective pharmacological inhibitors were used. As shown in Fig. 7a, pretreatment with Act. D $(10 \mu \mathrm{M})$, CHI $(1 \mu \mathrm{M})$, TNFR nAb $(3 \mu \mathrm{g} / \mathrm{ml})$,

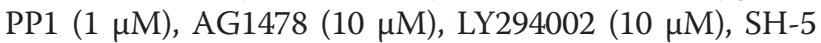
$(1 \mu \mathrm{M})$, or Bay11-7082 (3 $\mu \mathrm{M})$ markedly blocked the adhering of THP- 1 to TNF- $\alpha$-challenged HCFs. These results indicated that TNF- $\alpha$-induced VCAM-1 expression is mediated through a c-Src-dependent EGFR/ $\mathrm{PI} 3 \mathrm{~K} / \mathrm{Akt} / \mathrm{NF}-\mathrm{kB}$ pathway which also contributes to enhancement of monocyte adhering to these TNF- $\alpha$ induced HCFs.

\section{Discussion}

Up-regulation of adhesion molecules on the surface of the heart cells may play a key role in recruitment and infiltration of leukocytes at sites of inflammation in heart inflammatory disorders $[8,23,24,26]$. Cardiac fibroblasts play critical role in the development of cardiac fibrosis $[4,10,11,42]$. Previous reports indicate that TNF- $\alpha$-treatment can induce VCAM-1 expression in rat primary cardiac fibroblasts [43] and mediate the monocyte adhesion $[44,45]$. We found that VCAM-1 nAb can reduce the monocyte adhesion (about $37 \%$ ) on HCFs challenged with TNF- $\alpha$ (Fig. 1d). However, TNFR nAb treatment can reduce the monocyte adhesion on HCFs about $73 \%$ (Fig. 7a). We suggest that TNF- $\alpha$ induces not only VCAM-1 but also other adhesion molecules on HCFs which contribute to monocyte adhesion.

Previous study indicates that serum TNF- $\alpha$ concentrations of chronic heart failure patients $(4.5 \pm 0.5 \mathrm{pg} / \mathrm{ml})$ are higher than normal $(2.6 \pm 0.4 \mathrm{pg} / \mathrm{ml})$ [46]. However, treatments with these concentrations could not induce a significant gene expression in our system (data not shown). To obtain the optimal VCAM-1 expression, the higher concentrations of TNF- $\alpha$ were used to challenge HCFs. TNF- $\alpha$ has been confirmed to induce the expression of VCAM-1 in synovial fibroblasts [33]. Moreover, TNF- $\alpha$ has also been shown to activate various signals including MAPKs in several cell types [6,33], but the intracellular signaling mechanisms leading to VCAM-1 expression remain unclear in HCFs. Transactivation of the receptor tyrosine kinases (RTKs), EGFR especially, has been shown to occur in response to several cytokines such as TNF- $\alpha$ [47], which might contribute to various cellular functions [35]. Although transactivation of EGFR by GPCR agonists has been well studied $[35,48]$, the signaling mechanisms by which TNF- $\alpha$-stimulated transactivation of EGFR in HCFs remain unclear.

In this study, up-regulation of VCAM- 1 by TNF- $\alpha$ is mediated through transactivation of $\mathrm{c}$-Src/EGFR which were attenuated by their respective inhibitors (PP1 and AG1478) and siRNAs transfection, suggesting the involvement of c-Src/EGFR in these responses (Figs. 3 and 4). In addition, we found that EGFR was 


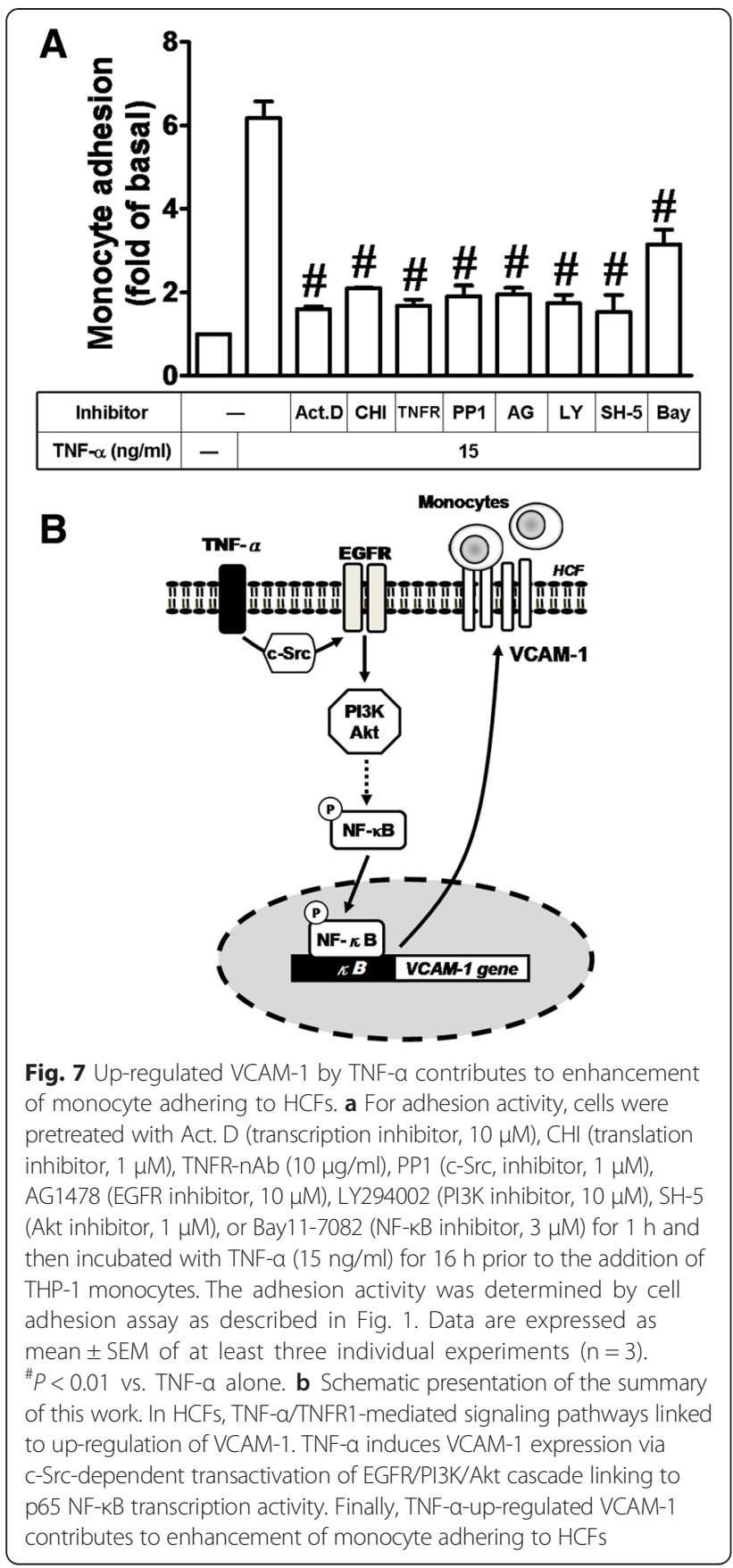

a downstream component of c-Src, since TNF- $\alpha$ induced EGFR phosphorylation was attenuated by PP1 (Fig. 4e), whereas AG1478 had no effect on c-Src phosphorylation (data not shown), and subsequent up-regulation of VCAM-1 and adhesion of monocytes (Fig. 7a). These results suggested that transactivation of EGFR plays a critical role in TNF- $\alpha$-induced VCAM-1 expression and monocyte adhesion, consistent with previous report showing the involvement of EGFR transactivation in TNF- $\alpha$-induced VCAM-1 expression in human tracheal smooth muscle cells (HTSMCs) [40].

The PI3K/Akt cascade is the downstream components of EGFR activation, which is implicated in the pathogenesis of inflammatory responses $[49,50]$ through the induction of inflammatory gene expression [40,51]. PI3K could initiate a series of events that lead to Akt activation [52]. Moreover, TNF- $\alpha$-stimulated activation of PI3K/Akt pathway has been reported in various cell types [6, 22]. As expected, our results also showed that both the inhibitors of PI3K (LY294002) and Akt (SH-5) could significantly attenuate the TNF- $\alpha$-induced VCAM-1 expression (Fig. 5a) and monocyte adhesion (Fig. 7a). We further confirmed this hypothesis by the results that transfection with p110 siRNA (a PI3K subunit) or Akt siRNA also attenuated the TNF- $\alpha$-induced VCAM-1expression (Fig. $5 \mathrm{~d}$ ). Altogether, these results suggested that VCAM-1 induction by TNF- $\alpha$ is mediated through a PI3K/Akt-dependent cascade in HCFs, consistent with previous study that PI3K/Akt cascade may be an important pathway in regulating VCAM-1 expression by TNF- $\alpha$ in various cell types $[40,41]$. Moreover, TNF- $\alpha$-stimulated Akt phosphorylation was attenuated by the inhibitors of TNFR nAb, c-Src siRNA, EGFR (AG1478) (Fig. 5e) and PI3K (LY294002) (Fig. 5c). These results indicated that TNF- $\alpha$-induced VCAM- 1 expression may be sequentially mediated through a c-Src-dependent EGFR/PI3K/Akt cascade in HCFs.

Inflammatory responses following exposure to cytokines are highly dependent on activation of NF- $\mathrm{kB}$ which plays an important role in expression of several inflammatory genes [17, 18, 53]. NF-kB activity is increased and critically implicates in the development of cardiac fibrosis and pathologic cardiac remodeling. Moreover, $\mathrm{NF}-\mathrm{kB}$ is a key regulator in myofibroblast differentiation [54]. Our previous study also demonstrated that c-Srcdependent NF- $\mathrm{KB}$ activation is essential for the expression of VCAM-1 induced by TNF- $\alpha$ in HTSMCs, synovial fibroblasts and osteoblast-like MC3T3-E1 cells $[33,34,47]$. In the present study, the role of NF-kB in TNF- $\alpha$-induced VCAM-1 expression is confirmed by an NF- $k B$ inhibitor (Bay11-7082, Fig. 6a) and p65 siRNA transfection (Fig. 6d), indicating that NF- $\kappa B$ involves in TNF- $\alpha$-induced VCAM-1 expression. Moreover, we found that the increase in $\mathrm{p} 65 \mathrm{NF}-\mathrm{\kappa B}$ phosphorylation correlates with an increase of NF- $\mathrm{B}$ B transcriptional activity induced by TNF- $\alpha$ (Figs. 6e and f, upper panel). TNF- $\alpha$-stimulated p65 phosphorylation and transcriptional activity is attenuated by PP1, AG1478, LY294002, and Bay11-7082 or transfection with $\mathrm{c}$-Src and Akt siRNAs (Figs. 6e and f, lower panel), suggesting that TNF$\alpha$-stimulated NF- $\mathrm{KB}$ activation is mediated through a cSrc-dependent transactivation EGFR/PI3K/Akt cascade in HCFs. These findings are consistent with several reports 
indicating that activation of NF- $\mathrm{BB}$ is mediated via EGFR/ PI3K/Akt in various cell types $[55,56]$. However, studies on the role of the PI3K/Akt pathway in NF-kB-dependent gene expression are controversial. Our previous study shows that TNF- $\alpha$-induced MMP-9 expression via NF-kB activation is independent on the PI3K/Akt cascade in HTSMCs [21]. The recent reports also indicate that MMP-9 is a responsive gene of NF- $\mathrm{kB}$ and AP-1 [57] and the necrotic cardiomyocytes can release heat-labile proinflammatory signal to activate NF- $\mathrm{KB}$ in cardiac fibroblasts [58].

The infiltration of immune cells is due to upregulation of adhesion molecules including ICAM-1 and VCAM-1 [23, 24, 26] which contribute to several chronic inflammatory diseases including cardiovascular diseases. Moreover, the elevated levels of ICAM-1 and VCAM-1 are often found in the serum of patients with non-ischemic heart failure. These raised serum levels of adhesion molecules correlate with inflammatory infiltrates in the myocardial tissue [27]. The VCAM-1, which exhibits low to negligible expression on un-stimulated endothelial cells, can be profoundly up-regulated by cytokines. The cardiac fibroblasts are versatile cells with the potential to activate an array of genes that are able to initiate and propagate inflammation in heart diseases. Upregulation of VCAM-1 and TNF- $\alpha$ has been shown in the cardiac vascular endothelium from patients with chronic heart failure [27, 30]. However, the effects of TNF- $\alpha$-induced VCAM-1 expression between cardiac fibroblasts and immune cells remain unclear. In this study, we demonstrated that TNF- $\alpha$ enhanced monocyte adhesion through up-regulation of VCAM1 , as a marker of immune cell infiltration (Fig. 1d). Moreover, these signaling components of VCAM-1 induction by TNF- $\alpha$ were involved in TNF- $\alpha$-enhanced monocyte adhesion attenuated by their respective pharmacological inhibitors (Fig. 7a). These results indicated that TNF- $\alpha$-induced VCAM-1 expression via a c-Src-dependent transactivation of EGFR/PI3K/Akt links to NF-kB pathway which increases the monocytes adhered to TNF- $\alpha$-challenged HCFs. These results are consistent with reports indicating that TNF- $\alpha$ enhanced immune cells adhesion via increased VCAM-1 expression in RASFs or HTSMCs $[33,40]$. Therefore, infiltration of immune cells into myocardium exerts bidirectional cross talk with HCFs which can be mediated by paracrine signals, direct cell-cell interactions, and indirect interaction via ECM. Both cell types and their cross talk are important determinants of structural, mechanical characteristics in the healthy and remodeled myocardium [59]. Cardiac fibroblasts play many of roles in cardiac development and remodeling. HCFs are the predominant type of cells involved in ECM turnover and deposition in the heart [60], which leads to excessive deposition of ECM and fibroblast accumulation and results in distorted organ architecture and function.

\section{Conclusions}

In summary, we reported here that TNF- $\alpha$ induced the expression of VCAM-1 gene in HCFs. The TNFR1, с-Src, EGFR, PI3K/Akt, and NF-кB cooperatively mediated these effects of TNF- $\alpha$. Based on the observations from literatures and our findings, Fig. 7b depicts a model for the signaling mechanisms implicated in TNF$\alpha$-induced VCAM- 1 expression in HCFs. These findings suggest that TNF- $\alpha$-induced VCAM-1 expression might play a critical role in heart inflammatory disorders mediated through $\mathrm{c}$-Src-dependent transactivation of EGFR, PI3K/Akt, and NF-kB signaling pathways in HCFs. The results provide new insights into the mechanisms of TNF- $\alpha$ action on HCFs to up-regulate the VCAM-1 expression and then amplified the inflammatory responses, supporting the hypothesis that TNF- $\alpha$ may play a key role in the development of cardiac diseases.

\section{Abbreviations}

TNF-a: tumor necrosis factor-a; VCAM-1: vascular cell adhesion molecule-1; HCFs: human cardiac fibroblasts; NF-KB: Nuclear factor-kB; EGFR: EGF receptor; DMEM/F-12: Dulbecco's modified Eagle's medium/Ham's nutrient mixture F-12; FBS: fetal bovine serum; Act. D: Actinomycin D;

CHI: cycloheximide; ECL: enhanced chemiluminescence; BCA: bicinchoninic acid; PMNs: polymorphonuclear cells; PBS: phosphate-buffered saline; GPCR: G protein-coupled receptor; siRNA: small interfering RNA;

PCR: polymerase chain reaction; RTKs: receptor tyrosine kinases; TNFR1: TNF receptor 1; XTT: (sodium 3'-[1-(phenylamino-carbonyl)-3,4-tetrazolium]-bis (4-methoxy-6-nitro) benzene sulphonic acid hydrate.

\section{Competing interests}

The authors declare that they have no competing interests related to this work.

\section{Authors' contributions}

Conceived and designed the experiments: CCL, CSP, CYW, SWL, LDH, CMY. Performed the experiments: CCL, CSP, SWL, LDH. Analyzed the data: CCL, CSP, CYW, SWL, LDH, CMY. Contributed reagents/materials/analysis tools: CCL, CSP, LDH, CMY. Wrote the paper: CCL, CYW, CMY. All authors read and approved the final manuscript.

\section{Acknowledgements}

This work was supported by Ministry of Science and Technology, Taiwan; Grant number: MOST103-2321-B-182-006 and MOST101-2320-B-182-039-MY3; Chang Gung Medical Research Foundation, Grant number: CMRPD1C0102, CMRPD1C0103, CMRPD1C0562, CMRPD1C0563, CMRPD1B0332,

CMRPG3B1093, and CMRPG3C1303; and the Ministry of Education, Taiwan; Grant number: EMRPD1E1641.

\section{Author details}

'Department of Anesthetics, Chang Gung Memorial Hospital at Linkuo, Kwei-Shan, Tao-Yuan, Taiwan. ${ }^{2}$ College of Medicine, Chang Gung University, Kwei-Shan, Tao-Yuan, Taiwan. ${ }^{3}$ Department of Physiology, College of Medicine, Chang Gung University, Kwei-Shan, Tao-Yuan, Taiwan.

${ }^{4}$ Department of Pharmacology and Health Aging Research Center, College of Medicine, Chang Gung University, 259 Wen-Hwa 1st Road, Kwei-Shan,

Tao-Yuan, Taiwan. 
Received: 8 January 2015 Accepted: 7 July 2015

\section{Published online: 15 July 2015}

\section{References}

1. Colucci WS, Braunwald E. Pathophysiology of heart failure. In: Zipes DP LP, Bonow RO, Braunwald E, editors. Braunwald's Heart Disease: A Textbook of Cardiovascular Medicine. 7th ed. Philadelphia, PA: Elsevier Saunders; 2005. p. 509-38.

2. Adams Jr KF. New epidemiologic perspectives concerning mild-to-moderate heart failure. Am J Med. 2001;110(Suppl 7A):6S-13S.

3. Zile MR, Baicu CF, Gaasch WH. Diastolic heart failure-abnormalities in active relaxation and passive stiffness of the left ventricle. $\mathrm{N}$ Engl J Med. 2004:350:1953-9.

4. See F, Kompa A, Martin J, Lewis DA, Krum H. Fibrosis as a therapeutic target post-myocardial infarction. Curr Pharm Des. 2005;11:477-87.

5. Palmer JN, Hartogensis WE, Patten M, Fortuin FD, Long CS. Interleukin-1 beta induces cardiac myocyte growth but inhibits cardiac fibroblast proliferation in culture. J Clin Invest. 1995;95:2555-64.

6. Yang CM, Lee IT, Lin CC, Wang CH, Cherng WJ, Hsiao LD. c-Src-dependent MAPKs/AP-1 activation is involved in TNF-alpha-induced matrix metalloproteinase-9 expression in rat heart-derived $\mathrm{H} 9 \mathrm{c} 2$ cells. Biochem Pharmacol. 2013:85:1115-23.

7. Yokoyama T, Nakano M, Bednarczyk JL, McIntyre BW, Entman M, Mann DL. Tumor necrosis factor-alpha provokes a hypertrophic growth response in adult cardiac myocytes. Circulation. 1997;95:1247-52.

8. Heymans S, Hirsch E, Anker SD, Aukrust P, Balligand J-L, Cohen-Tervaert JW, et al. Inflammation as a therapeutic target in heart failure? A scientific statement from the Translational Research Committee of the Heart Failure Association of the European Society of Cardiology. Eur J Heart Failure. 2009:11:119-29.

9. Koudssi F, Lopez JE, Villegas S, Long CS. Cardiac fibroblasts arrest at the $\mathrm{G} 1 / \mathrm{S}$ restriction point in response to interleukin (IL)-1beta. Evidence for IL-1 beta-induced hypophosphorylation of the retinoblastoma protein. J Biol Chem. 1998;273:25796-803.

10. Mitchell MD, Laird RE, Brown RD, Long CS. IL-1 beta stimulates rat cardiac fibroblast migration via MAP kinase pathways. Am J Physiol Heart Circ Physiol. 2007:292:H1139-1147.

11. Siwik DA, Chang DL, Colucci WS. Interleukin-1beta and tumor necrosis factor-alpha decrease collagen synthesis and increase matrix metalloproteinase activity in cardiac fibroblasts in vitro. Circ Res. 2000;86:1259-65

12. Torre-Amione G, Kapadia S, Benedict C, Oral H, Young JB, Mann DL. Proinflammatory cytokine levels in patients with depressed left ventricular ejection fraction: a report from the Studies of Left Ventricular Dysfunction (SOLVD). J Am Coll Cardiol. 1996;27:1201-6.

13. Saito Y, Watanabe K, Fujioka D, Nakamura T, Obata JE, Kawabata K, et al. Disruption of group IVA cytosolic phospholipase $A_{2}$ attenuates myocardial ischemia-reperfusion injury partly through inhibition of TNF-alpha-mediated pathway. Am J Physiol Heart Circ Physiol. 2012;302:H2018-2030.

14. Wang M, Gu H, Brewster BD, Huang C. Role of endogenous testosterone in TNF-induced myocardial injury in males. Int J Clin Exp Med. 2012;5:96-104.

15. Lee IT, Yang CM. Inflammatory signalings involved in airway and pulmonary diseases. Mediators Inflamm. 2013;2013:791231.

16. Lindner D, Zietsch C, Becher PM, Schulze K, Schultheiss H-P, Tschope C, et al. Differential expression of matrix metalloproteases in human fibroblasts with different origins. Biochem Res Int. 2012;2012:875742.

17. Barnes PJ, Karin M. Nuclear factor-kappaB: a pivotal transcription factor in chronic inflammatory diseases. N Engl J Med. 1997;336:1066-71.

18. Brasier AR. The NF-kappaB regulatory network. Cardiovasc Toxicol. 2006;6:111-30.

19. Lee IT, Yang C-M. Role of NADPH oxidase/ROS in pro-inflammatory mediators-induced airway and pulmonary diseases. Biochem Pharmacol. 2012;84:581-90.

20. Yang CM, Hsieh HL, Lee CW. Intracellular signaling mechanisms underlying the expression of pro-inflammatory mediators in airway diseases. Chang Gung Med J. 2005;28:813-23.

21. Hsieh HL, Sun CC, Wang TS, Yang CM. PKC-delta/c-Src-mediated EGF receptor transactivation regulates thrombin-induced COX-2 expression and $\mathrm{PGE}_{2}$ production in rat vascular smooth muscle cells. Biochim Biophys Acta. 2008;1783:1563-75.
22. Lee CW, Lin CC, Lin WN, Liang KC, Luo SF, Wu CB, et al. TNF-alpha induces MMP-9 expression via activation of Src/EGFR, PDGFR/PI3K/Akt cascade and promotion of NF-kappaB/p300 binding in human tracheal smooth muscle cells. Am J Physiol Lung Cell Mol Physiol. 2007;292:L799-812.

23. Cronstein BN. Adhesion molecules in the pathogenesis of rheumatoid arthritis. Curr Opin Rheumatol. 1994;6:300-4.

24. Frangogiannis NG, Smith CW, Entman ML. The inflammatory response in myocardial infarction. Cardiovasc Res. 2002;53:31-47.

25. Sprent J, Tough DF, Sun S. Factors controlling the turnover of T memory cells. Immunol Rev. 1997;156:79-85.

26. Szekanecz Z, Szegedi G, Koch AE. Cellular adhesion molecules in rheumatoid arthritis: regulation by cytokines and possible clinical importance. J Investig Med. 1996:44:124-35.

27. Klein RM, Breuer R, Mundhenke M, Schwartzkopff B, Strauer BE. Circulating adhesion molecules (CICAM-1, ICVCAM-1) in patients with suspected inflammatory heart muscle disease. Z Kardiol. 1998;87:84-93.

28. Dustin ML, Singer $\mathrm{KH}$, Tuck DT, Springer TA. Adhesion of T lymphoblasts to epidermal keratinocytes is regulated by interferon gamma and is mediated by intercellular adhesion molecule 1 (ICAM-1). J Exp Med. 1988;167:1323-40.

29. Javaid K, Rahman A, Anwar KN, Frey RS, Minshall RD, Malik AB. Tumor necrosis factor-alpha induces early-onset endothelial adhesivity by protein kinase Czeta-dependent activation of intercellular adhesion molecule-1. Circ Res. 2003;92:1089-97.

30. Savic-Radojevic A, Radovanovic S, Pekmezovic T, Pljesa-Ercegovac M, Simic D, Djukic T, et al. The role of serum VCAM-1 and TNF-alpha as predictors of mortality and morbidity in patients with chronic heart failure. J Clin Lab Anal. 2013;27:105-12.

31. Kim SH, Chang JW, Kim SB, Park SK, Park JS, Lee SK. Myoglobin induces vascular cell adhesion molecule-1 expression through c-Src kinase-activator protein-1/nuclear factor-kappaB pathways. Nephron Exp Nephrol. 2010:114:e48-60

32. Lin WN, Luo SF, Wu CB, Lin CC, Yang CM. Lipopolysaccharide induces VCAM-1 expression and neutrophil adhesion to human tracheal smooth muscle cells: involvement of Src/EGFR/PI3-K/Akt pathway. Toxicol Appl Pharmacol. 2008:228:256-68.

33. Luo SF, Fang RY, Hsieh HL, Chi PL, Lin CC, Hsiao LD, et al. Involvement of MAPKs and NF-kappaB in tumor necrosis factor alpha-induced vascular cell adhesion molecule 1 expression in human rheumatoid arthritis synovial fibroblasts. Arthritis Rheum. 2010;62:105-16.

34. Tsai CL, Chen WC, Hsieh HL, Chi PL, Hsiao LD, Yang CM. TNF-alpha induces matrix metalloproteinase-9-dependent soluble intercellular adhesion molecule-1 release via TRAF2-mediated MAPKs and NF-kappaB activation in osteoblast-like MC3T3-E1 cells. J Biomed Sci. 2014;21:12.

35. Luttrell LM, Della Rocca GJ, van Biesen T, Luttrell DK, Lefkowitz RJ. Gbetagamma subunits mediate Src-dependent phosphorylation of the epidermal growth factor receptor. A scaffold for $\mathrm{G}$ protein-coupled receptor-mediated Ras activation. J Biol Chem. 1997;272:4637-44.

36. leda M, Tsuchihashi T, Ivey KN, Ross RS, Hong T-T, Shaw RM, et al. Cardiac fibroblasts regulate myocardial proliferation through beta1 integrin signaling. Dev Cell. 2009;16:233-44.

37. Redondo J, Bishop JE, Wilkins MR. Effect of atrial natriuretic peptide and cyclic GMP phosphodiesterase inhibition on collagen synthesis by adult cardiac fibroblasts. Br J Pharmacol. 1998;124:1455-62.

38. Hsieh HL, Sun CC, Wu CB, Wu CY, Tung WH, Wang HH, et al. Sphingosine 1phosphate induces EGFR expression via Akt/NF-kappaB and ERK/AP-1 pathways in rat vascular smooth muscle cells. J Cell Biochem. 2008;103:1732-46.

39. Livak KJ, Schmittgen TD. Analysis of relative gene expression data using real-time quantitative PCR and the 2(-Delta Delta C(T)) Method. Methods. 2001;25:402-8

40. Lee CW, Lin CC, Luo SF, Lee HC, Lee IT, Aird WC, et al. Tumor necrosis factor-alpha enhances neutrophil adhesiveness: induction of vascular cell adhesion molecule-1 via activation of Akt and CaM kinase II and modifications of histone acetyltransferase and histone deacetylase 4 in human tracheal smooth muscle cells. Mol Pharmacol. 2008;73:1454-64.

41. Tsoyi K, Jang HJ, Nizamutdinova IT, Park K, Kim YM, Kim HJ, et al. PTEN differentially regulates expressions of ICAM-1 and VCAM-1 through PI3K/Akt/ GSK-3beta/GATA-6 signaling pathways in TNF-alpha-activated human endothelial cells. Atherosclerosis. 2010;213:115-21.

42. Takeda N, Manabe I. Cellular Interplay between Cardiomyocytes and Nonmyocytes in Cardiac Remodeling. Int J Inflam. 2011;2011:535241. 
43. Kacimi R, Karliner JS, Koudssi F, Long CS. Expression and regulation of adhesion molecules in cardiac cells by cytokines: response to acute hypoxia. Circ Res. 1998;82:576-86.

44. Shang XZ, Lang BJ, Issekutz AC. Adhesion molecule mechanisms mediating monocyte migration through synovial fibroblast and endothelium barriers: role for CD11/CD18, very late antigen-4 (CD49d/CD29), very late antigen-5 (CD49e/CD29), and vascular cell adhesion molecule-1 (CD106). J Immunol. 1998;160:467-74.

45. Schmitz B, Vischer P, Brand E, Schmidt-Petersen K, Korb-Pap A, Guske K, et al. Increased monocyte adhesion by endothelial expression of VCAM-1 missense variation invitro. Atherosclerosis. 2013;230:185-90.

46. Sharma R, von Haehling S, Rauchhaus M, Bolger AP, Genth-Zotz S, Doehner $W$, et al. Whole blood endotoxin responsiveness in patients with chronic heart failure: the importance of serum lipoproteins. Eur J Heart Fail. 2005;7:479-84.

47. Lee CW, Lin WN, Lin CC, Luo SF, Wang JS, Pouyssegur J, et al. Transcriptional regulation of VCAM-1 expression by tumor necrosis factor-alpha in human tracheal smooth muscle cells: involvement of MAPKs, NF-kappaB, p300, and histone acetylation. J Cell Physiol. 2006;207:174-86.

48. Wetzker R, Bohmer FD. Transactivation joins multiple tracks to the ERK MAPK cascade. Nat Rev Mol Cell Biol. 2003;4:651-7.

49. Kim D, Kim S, Koh H, Yoon SO, Chung AS, Cho KS, et al. Akt/PKB promotes cancer cell invasion via increased motility and metalloproteinase production. FASEB J. 2001;15:1953-62.

50. Koyasu S. The role of PI3K in immune cells. Nat Immunol. 2003;4:313-9.

51. Sheu ML, Chao KF, Sung YJ, Lin WW, Lin-Shiau SY, Liu SH. Activation of phosphoinositide 3-kinase in response to inflammation and nitric oxide leads to the up-regulation of cyclooxygenase-2 expression and subsequent cell proliferation in mesangial cells. Cell Signal. 2005;17:975-84.

52. Brazil DP, Hemmings BA. Ten years of protein kinase B signalling: a hard Akt to follow. Trends Biochem Sci. 2001;26:657-64.

53. Collins T, Read MA, Neish AS, Whitley MZ, Thanos D, Maniatis T. Transcriptional regulation of endothelial cell adhesion molecules: NF-kappa B and cytokine-inducible enhancers. FASEB J. 1995;9:899-909.

54. Tian K, Liu Z, Wang J, Xu S, You T, Liu P. Sirtuin-6 inhibits cardiac fibroblasts differentiation into myofibroblasts via inactivation of nuclear factor kappaB signaling. Transl Res. 2015;165:374-86.

55. Gustin JA, Ozes ON, Akca H, Pincheira R, Mayo LD, Li Q, et al. Cell type-specific expression of the IkappaB kinases determines the significance of phosphatidylinositol 3-kinase/Akt signaling to NF-kappa B activation. J Biol Chem. 2004;279:1615-20.

56. Ozes ON, Mayo LD, Gustin JA, Pfeffer SR, Pfeffer LM, Donner DB. NF-kappaB activation by tumour necrosis factor requires the Akt serine-threonine kinase. Nature. 1999;401:82-5.

57. Siddesha JM, Valente AJ, Sakamuri SSVP, Gardner JD, Delafontaine P, Noda M, et al. Acetylsalicylic acid inhibits IL-18-induced cardiac fibroblast migration through the induction of RECK. J Cell Physiol. 2014;229:845-55.

58. Lugrin J, Parapanov R, Rosenblatt-Velin N, Rignault-Clerc S, Feihl F, Waeber B, et al. Cutting edge: IL-1alpha is a crucial danger signal triggering acute myocardial inflammation during myocardial infarction. J Immunol. 2015;194:499-503.

59. Zhang P, Su J, Mende U. Cross talk between cardiac myocytes and fibroblasts: from multiscale investigative approaches to mechanisms and functional consequences. Am J Physiol Heart Circ Physiol. 2012;303:H1385-1396.

60. Sullivan KE, Black LD. The role of cardiac fibroblasts in extracellular matrix-mediated signaling during normal and pathological cardiac development. J Biomech Eng. 2013;135:71001.

\section{Submit your next manuscript to BioMed Central and take full advantage of:}

- Convenient online submission

- Thorough peer review

- No space constraints or color figure charges

- Immediate publication on acceptance

- Inclusion in PubMed, CAS, Scopus and Google Scholar

- Research which is freely available for redistribution

Submit your manuscript at www.biomedcentral.com/submit 